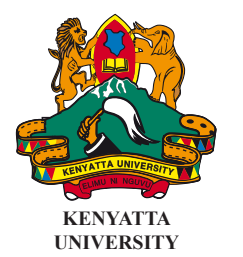

ISSN 1563-1028
CHEMCHEMI

International Journal of Humanities and Social Sciences

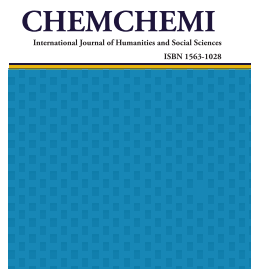

Volume 10 Number 2, 2016

OPEN ACCESS

\title{
THE CHALLENGE OF TEACHING IN A SECOND/FOREIGN LANGUAGE AND ALTERNATIVE APPROACHES TO DEVELOPING FLUENCY IN THE LANGUAGES OF INSTRUCTION
}

\author{
Jane Kembo
}

\begin{abstract}
Teaching at the university makes me realize that something needs to be done in the teaching of language for learning. Observation shows that students arrive at university without the requisite language skills (Tekeste, 2006; Aspen, et al., 2009), to benefit fully from the kind of independent work that is expected of them, and that should, by and large, be buttressed by ingrained language and study skills which they should have acquired and honed at secondary school. In addition, more than half of the students I teach at university cannot succinctly express themselves in English and are unable to write effectively in English, the language of instruction. The studies cited in the paper are not confined to Kenya; there is the SAQMEC II Study which covered 15 African countries at primary level. The UWEZO study of 2012 covered Kenya, Uganda and Tanzania, while the report on Ethiopia covers the Ethiopian situation. The study covered undergraduate writing errors from 201 students, while the Ethiopian data covers PhD theses from 7 candidates. What the data shows is that mastery of the language of instruction across the board is not what it should be and candidates struggle to express themselves both in writing and speech. In attending $\mathrm{PhD}$ vivas, I have come across candidates who are unable to express themselves orally using English, even when they are English language majors. The paper argues, based on existing research, that language is a big determinant of reading (Winne, 1993; Kinstch, 1991; Olshavksy 1977; Kembo, 1994, which, in turn, is a big part of independent learning, thereby determining school success. The paper further contends that in circumstances where input from the environment is limited, as is often the case in most second and foreign language contexts, the student must be aided to get it from alternative sources: extensive reading programs that are monitored until they become habitual, clubs, listening to radio and television as part of teaching and learning, production and use of self-learning materials that learners can utilize in schools and at home at affordable costs. Alternatively, we must revert to the use of African languages because of the benefits accruing: early mastery, conceptualization of the world, fluency, and the freedom to use their mental capacities and resources for grappling with content rather than with mastery of language at the same time.
\end{abstract}

Key words: Foreign language, language of instruction, alternative approaches, language policy, language competency, mother-tongue, performance 


\section{Introduction}

Bryant and Bradley (1985, p. 1) state that:

'Of all the things that children have to learn when they go to schools, reading and writing are the most basic, the most central and the most critical. Practically, everything else that they do will be permeated by these skills. Hardly a lesson can be understood; hardly a project can be finished unless children can read the books in front of them and write assignments given to them.'

Alternatively phrased, we can state that language and language use is the fulcrum on which education and learning turn. A child's proficiency and success in education is determined by how wide their vocabulary is and how well they can operate in a given language of instruction.

To understand content in diverse subjects, instruction and questions in examinations, tests, experiments, and in general life (drugs, posters), learners need to comprehend, analyze, interpret, synthesize, compare and contrast information before them (Winne, 1993; Weaver and Kintsh, 1991; Kembo, 2012). The capacity of learners to do all this and more is predicated on their language proficiency and their ability to use language to attack tasks before them appropriately (Chikalanga, 1991; Kembo, 1997; Lubelska, 1991). The problem of language of instruction and learning, therefore, are not new as will be shown by more recent studies.

Section one of the paper sets the question in context, the second section briefly discusses language and formal schooling, while the third section examines data from researches on the use of language and school performance in addition to looking at errors made in the written work of university students. The fourth part of the paper looks at options available, while the last portion of the paper makes a case for the use of mother tongues as one of the alternatives, as well as making recommendations on options available for schools to make better proficiencies possible in the languages of instruction.

\section{Education and Language}

Language is the prism through which human beings give meaning to the world around them. It is through language that we acquire our literacy (Kembo, 1994). Language assists cognitive development and interaction with the human environment.

While many of the students know that they need English for social mobility, they often think that Kiswahili in Kenya, which is an alternative language, will do especially now that it is an examination subject in Kenya. In fact, many of them do not master either (Kembo Sure, 1995). Edwards and Nwenmely (1995) observed a similar scenario in the Carribean in 1995. The Kenya National Exams Council (KNEC) reports each year lament the poor mastery of English language, and state that students generally have two major problems: lack of understanding of examination rubric and questions in English. In addition, the reports state that when the candidates seem to understand questions, they are often at a loss because they lack the language in which to express that 'which they may know' (KCSE and KNEC reports: 2010, 2012, 2008 and 2012).

\section{Language Policy and Language Competencies}

In Kenya the language policy is that pupils in lower primary 1 to 3 learn in mother tongue (MT), which is usually one of the vernacular languages (Dholuo, Ulluhya, Ekigusii, Gikuyu, etc), or Kiswahili, if the catchment is of mixed linguistic groups as happens in urban and peri-urban centres. In some urban and high cost schools, there is often the use of English to teach learners. Whatever the foundation, all learners are supposed to transit to English as the language of instruction from primary 4 onwards. The reality is often far from this.

In Malawi, the policy is that most children learn in Chichewa up to Standard 3. They do their first readings and numeracy classes in Chichewa. In Zambia, however, children learn in English from Standard 
1. In Tanzania, Kiswahili, which is widely spoken, is the language of learning for most of the primary school, with English taught as a subject. In Ethiopia, children learn in Amharic at both primary and secondary school, with English taught as a subject. When students reach secondary school and university they are supposed to have learned adequate English to cope with both the extended writing and reading they must do in English.

\section{Studies of Primary Pupils' Performance}

In Kenya, even though parents and teachers are agreed on the advantages that they perceive to exist in the use of English for Kenyan children, research in the primary school classrooms indicates that after six years of primary education (3 years mother tongue and 3 years of instruction in English medium, Kenyan children can hardly read meaningfully in English (Nzomo, et al, 2000). This is what the report states:

"These figures indicate the need for a major Ministry review of policy related to the development of literacy skills in Kenyan primary schools. It is not acceptable that only around two-thirds of Standard 6 pupils reach the minimum level of literacy, and only around one quarter reach desirable level" (Nzomo et al, 2000).

Exam results (KNEC, 2011, 2012; Ethiopia, 2011) discuss the following as weaknesses that prevent children from performing well in national examinations. All the reports identify lack of adequate mastery of the language of instruction to:

- Understand concepts adequately

- Failure to read questions with understanding, and

- Lack of language to express what they know, especially in open ended questions.

Research by Cummins, (1979, 1984) and Williams (1996) among others, demonstrate that learning in the child's first language facilitates acquisition of a second language. Malawi where children learned in Chichewa and Zambia where they learned in English are cases in point. The children in Malawi developed better reading and numeracy skills by Standard five than the children in Zambia.

In addition, the SACMEQ III Survey of 2010 examined Grade 6 pupils on reading, Math, and health and covered the following 15 countries in the continent: Botswana, Kenya, Lesotho, Malawi, Mauritius, Mozambique, Namibia, Seychelles, South Africa, Swaziland, Tanzania, Uganda, Zambia, Zanzibar and Zimbabwe.

The teacher sample consisted of:

\section{Subject taught}

Reading teachers

Math teachers

Health teachers

\section{Numbers in the study}

498

498

492

In the South African phase, the study surveyed 9083 Grade 6 students and 1488 teachers from 392 schools and had the following findings which are of interest to this paper. For example, South Africa which has more qualified teachers, lower pupil-teacher ratios, and better access to resources, did not necessarily outperform other countries. It was 13 th of 15 in the performance of rural students reading score, $9^{\text {th }}$ out 15 urban reading scores, $8^{\text {th }}$ out of 15 in urban Math performance and 12 out of 15 for rural students in overall performance. Tanzania outperformed South Africa in every sub-population (i.e., rural-urban, rich poor, male-female - overall) in spite of the South Africa's GDP per capita being \$5,786 which is eleven times higher than that of Tanzania (\$509). South Africa was also outperformed by Malawi and Mozambique. 
The fact that in the tests, Tanzania, and Malawi with less resources available for education, outperformed South Africa points to the language policy, that of using the language of the home, which is often not English, to introduce children to literacy, numeracy and other subjects especially in classes 1 to 3 . In Tanzania it is Kiswahili which virtually everyone speaks, while in Malawi, it is Chichewa.

In Kenya, where it has been shown that both teachers and children struggle with communication and understanding content in the language of instruction (Kembo-Sure, 1995; Kembo, 1994; Kembo, 2012), we are discussing a lethal mix that short-circuits any meaningful learning, especially at the primary school. In the light of the comments that are foregoing, we argue that continuing to insist on teaching and learning using foreign and second languages benefits very few recipients and leaves more victims than victors in its wake. The 2005 UNESCO Report (UNESCO, 2004) entitled The Quality Imperative emphasized that education quality should go beyond achievement and sustenance of expanded education by ensuring that schooling benefits individuals and societies (Barrett, 2013). Incidentally, in the examination of PhD candidates from Ethiopia, there was experience of similar language errors of syntax, concord and plenty of breakdown errors that totally obscure communication.

According to UWEZO 2012 report only 51 per cent of Tanzanian children in Standard Seven passed the Uwezo English test and only 68\% in Standard Seven passed the Standard Two numeracy test (UWEZO, 2012). This is worrying. In Ethiopia, where they use Amharic for all other transactions in the public domain except for learning at high school and university level, the following comments are registered about students' English:

Students do not possess sufficient English even to understand what they hear from their teachers or read in their textbooks, let alone to participate actively through their own speaking and writing. As a result of the inability of students to function through English, the quality of teaching and learning in schools has been very adversely affected (Tekeste, 2006 P. 6-7).

Amlaku (2010, p. 8-10) makes the following observations:

"Presently, teachers at schools and employers in industries have been complaining about the low level English language competence of students and graduates respectively (sic). Students who join colleges and universities are unable to express themselves in English well; graduates who join the world of work fail to write their own $C V$ and application letters for job. Teachers in primary and secondary schools and even in colleges and universities lack the proficiency to teach well and become role-models."

From these arguments, it seems that there is general Language-of-Instruction deficiency in many schools and universities across Africa. The basic question to ask of every child is: does he or she have the language to interact effectively with school content? This paper argues, based on research findings above and observations of performance from university students in the language of instruction - English, that students do not seem to develop adequate facility in the language to be able to cope with the independent learning required of them at increasingly difficult levels as they move from one class and level to another.

\section{Methodology}

The main objective of this study was to find out whether progression at university makes a difference in terms of quantity and seriousness of errors. The samples from which the mistakes were drawn came from four written assignments from 108 students of English language and communication skills. The students were all given two writing assignments over one month. The first task was to write on "the challenges of university students" while the second assignment was on the "the advantages and disadvantages of devolution'. Both were on topical issues and assumed to be of interest to the students. The students had two weeks to research on the topics and write before submitting their work. 


\section{Findings of the Study}

The research findings show that the errors that students in these two cohorts made in their communication in English language range from spelling, concord, syntax, mother tongue influence to break-down. The breakdown errors are those that a native speaker would find difficult to understand. There are many of these errors and they were committed by nearly $75 \%$ of the students sampled. The errors were distributed in the first year and third year by category as follows:

Table 1: Error Type by Percentage of Students Making Them

\begin{tabular}{|l|l|l|}
\hline \multirow{2}{*}{ Error type } & \multicolumn{2}{|c|}{ Percentage of students making errors by class } \\
\cline { 2 - 3 } & 1st years & 3rd year majors \\
\hline Spelling & 90 & 85 \\
\hline Concordance & 87 & 79 \\
\hline Syntax & 91 & 79 \\
\hline Mother tongue influence & 87 & 80 \\
\hline Breakdown errors & 78 & 65 \\
\hline
\end{tabular}

Source: Fieldwork

Table 1 shows that spelling errors were the most frequently made by students both in first year and by English Majors in third year. It also shows that both student groups have problems with verb-subject agreement at all levels producing sentences such as: 'groups encourages', 'learners gains', 'he do his works', they does not remember what they have learned'.

It can be observed that the occurrence of spelling and concordance errors are not significantly different among the third and first year students. The 1275 spelling errors and 1290 concordance errors were tested for significance at the $p<0.5$ level using the $\mathrm{t}$-test. There were no statistically significant differences $(\mathrm{t}=$ $1.295, \mathrm{df}=149)$. The same was true of the concordance errors $(\mathrm{t}=1.272, \mathrm{df}=149)$. This means that as they begin their university studies and even after they reach third year, learners have persistent spelling errors and concordance errors that are not likely to go away by the time they leave college. The fact that spelling and concordance errors were made by about $90 \%$ of students from both groups is worthy of note. Syntactic errors were made by a slightly lower percentage of students: $91 \%$ of first years and $79 \%$ of third years respectively. This may be deceptive as some of the syntax errors actually resulted in breakdown in communication. Seemingly, some of the errors are a result of both mother tongue influence and Kiswahili syntax which students use more often than they do English in their communication with each other and informally.

More serious errors were those of syntax and breakdown that obscure and short circuit communication altogether. Results show that more than $60 \%$ of all the students in first year and English Majors in the third year made breakdown errors. There were more breakdown and syntactic errors from the first years than from those in third year.

\section{Some Examples of Errors from Students' Work:}

i. Introductions tell us how the work will be.

ii. Group discussion enables competence of learners as they practice leadership role in their own hence remains forcust for feature life.

iii. When taking notes in the process of lecture will enable the learner to remember what the topic is about and the sentence body entails.

iv. People get to know where they belong interms of academic.

v. Due lack of parental, some student could not go through degree programme

vi. They should afail themselves in group works

vii. More people are being administered to learn 
viii. Before a student goes to study he or she must be aware so as to be prepared sycologically

ix. The learner should be at a position of course outline which will enable him to mark possible question.

x. $\quad$ Groups encourage students to make researches in different aspects of views.

\section{Discussion}

It has been observed even in the English classes that students will attempt to explain themselves in Kiswahili when they cannot find appropriate words to express ideas. Observations and experience with English majors in the third year show that Code-mixing and switching is always attempted even in the English classes. It is worthy to note that students even in the third year of study still make plenty of syntactical and break-down errors that short-circuit communication.

It is possible that by the time students reach third year, many of their errors have fully atrophied. The suggestion here is that if the students are going to be teachers, then they are likely to pass-on similar mis-learnings or lack of mastery to their learners. Language is meant for communication, and if learners cannot communicate effectively, they cannot express themselves effectively to others, in examinations and cannot meet demands of precise communication. It is worth noting that poor spelling and concordance seem to persist into university. In typed work, sometimes the spelling of a word may change the meaning of sentence, thus giving it un-intended meaning.

The evidence of inadequacy of English language that short-circuit learning is carried over from primary school to secondary and tertiary learning. Because learners do not master the languages of instruction adequately to be able to use it effectively as a tool for learning, their learning suffers as well.

In addition, for those who become teachers, the deficit is ploughed back into the learners that are taught by deficient teachers of language and other subjects. What this means is that both the teaching of other subjects and languages suffer, creating a vicious cycle that is difficult to break. This is shown in the tests that show that both Math and reading are not well grounded up to Standard Six, a few years before learners have to sit for exit examinations from that stage of learning. If pupils in Standard Six cannot perform reading and Math meant for Standard Two, then there is a big problem in schooling and learning. One of the things that this could mean is that the transition from the language of the locality or catchment area' is not taking place smoothly as envisaged in the policies of the countries. Alternatively, it could mean that subtractive multilingualism is rampant, as children and learners lose facility in their first languages, while not gaining it in the second language that is meant to be used for learning at school. The deficiency that persists, as seen from mistakes from undergraduates and comments from research studies in Ethiopia, show that schools'systems and policy require radical thinking with respect to languages that are used for teaching and learning. After all, what is the point of teaching in media that learners do not master? While the paper recognizes that the language question is a vexed one and that there is not one panacea for the problems in the education sector, there are alternatives that we can explore for the benefit of learners.

Some of the reasons that have been used to keep the status quo are the following:

- Absence of abstract terminology for science and technology. Is that true in the light of Japan and China?

- The costs that would be involved in providing multilingual services are prohibitive

- The need to develop and maintain national unity. Are the countries advancing these arguments? Are Kenya, for example, more united now than they were at independence?

- Poor financial situation in many Africa countries. Is it more cost effective to budget money that eventually goes to waste or money through which children can learn more effectively? Is it cheaper to waste half the population each year? 
- Shortage of professional translators and interpreters. How can we develop more translators when we do not need the services they offer?

\section{What are the Alternatives?}

In the following sections, the paper discusses the options that may be available in nations which use other languages that are not mother-tongue for teaching and learning. It discusses, in some detail, the extensive programmes, their benefits and how schools can raise books to encourage it. It also discusses teacher training and development options. The study also examines how self-learning materials may be produced locally and cheaply and how these could benefit learners. Considering that there is adequate evidence to argue that even at the university students do not learn maximally because of inadequate mastery of the languages of instruction - English in Kenya, Tanzania, Ethiopia ....Afrikaans and English in South Africa.

\section{The Mother-tongue Option}

The paper argues that Mother-tongue (MT) may be a better option for instruction in school, than Second Languages (SLs) or Foreign Languages (FLs). The question of which language to use in education is one that is tricky and loaded. It is at once political, economic and social. Political, because it is politics and politicians who often make the decision and legislation regarding the use of languages in their countries, and ensuing debates are often not necessarily logical, but loaded with emotions, and social overtones.

It is economic because it involves the considerations of cost and effectiveness, and budgets that must be taken into consideration. After all, no government has endless resources. It is also social, because the decision to elevate one language over others as languages of learning confers priority, privilege and power on the language and those who speak it (Kembo- Sure, 2013). The language question that is often not asked is usually whether the status quo is serving the needs of learners. These other considerations often outweigh the critical question: 'Are the children learning effectively in any designated language of instruction?'

The economists argue that changing to local languages would be too expensive to undertake. This may be true, but linguists would rightly argue that such a task would not be undertaken in whole at once. It would have to be implemented in incremental phases. Moreover, it is not necessary that all languages be used as languages for instruction and learning. Languages can be chosen within linguistic families for this purpose. Looking at the evidence and the question of language of the school, based on cost, this paper argues that economically it may be more cost-effective to let children learn in the language in which they are already proficient from home as well as already conceive the world, than in (a) language(s) in which both they and the teacher are struggling.

\section{The Place of Language in Cognition and Learning}

The understanding of the world depends on whether we can give names to phenomena around us, which, in turn, enables us to control the world. It is through language that we develop the identity and sense of belonging. Language sets human beings apart in enabling them to:

- Foster relationships by choice

- Think creatively and solve problems

- Develop identity/ies

- Come up with innovations

- Learn and share 
Take the example of this conversation between a child of primary school three and the author of the paper. Phylis is about 8 years old.

Adult: Nyingi ng'a?

(What is your name?)

Child: Phylis

Adult: Idhi sikul kanye?

(Where do you go to school?)

Child: Sare

Adult: Iwuotho?

(Do you go on foot?)

Child: Aa, aidho apiko.

(No, I board a motor bike)

Adult: Idhi gi apiko nang'o? skundu bor? (Why do you board a motor bikel is your school far?

Child: Bor marach! (Literally meaning: 'Badly far!' Or very far)

The ability of Phylis who lives within the linguistic community that she comes from enables the child to be creative with the language she speaks so that she can produce a sentence like the last one to describe, what in her estimation, is a school that is extremely far from her home. Her ability to manipulate the language at this stage and hold conversation in it is already quite advanced. If Phylis is already this proficient in the language of the home, would she not benefit more in school if learning was mediated in that language? What would the benefits of this be?

The language of the home fosters cognitive, social, as well as psychological development of the child. The child will learn best in the language they know and understand. The mother-tongue furthers their cognitive development and subject learning. Familiar experiences give a child a sense of security, and hasten the child's integration into the community.

When school uses the language of the home, the school as a system gives recognition and value to the language and culture (norms, conceptualizations, etc.) of the home that the child brings to school. In using the language of the home, the school builds on the experiences of the learner to enable him/her learn from known to unknown.

The language of the home is the language through which the child first forms their sense of identity, which is preserved through the language they speak. If the language is maintained, the child's identity is preserved so that creative and mental energies are directed towards learning new content. Thus, the perception of a child through his first language of who he is viz a viz who others are and, what roles they play form part of the values that they bring to school. Values that are useful can be reinforced to help a child learn better at school while those that are not socially acceptable can be left to die naturally through non-encouragement or negative reinforcement. Some evidence from research reveals that language can be a huge impediment to or facilitator of learning.

\section{The Extensive Reading (ER) Program in all Schools}

Apart from the Mother-tongue language, the other that has not received adequate attention as a means of acquiring target languages of instruction is Extensive Reading (ER). In circumstances where the learners speak one language during school time and another when they go back home and with their peers and friends, extensive reading programs need to be given due emphasis. Any language class provides little in terms of language in real use. Whether the teacher is innovative or not, is not the issue here. What is being debated is that any classroom provides limited input of the language that is being learned. At any rate, the language that is taught by the language department may, as observation shows, be short circuited by the language used by other subject teachers, who are not language specialists and by playground practice. ER refers to the less rigorously supervised reading that learners will do both in class and outside the classroom. The texts chosen will normally be those of their own choosing, even though the teacher's guidance will be crucial at the beginning. According to Kembo (1993) extensive reading exposes learners to different registers of the target language that they are likely to meet or use in varied contexts. Wide 
reading also broadens and increases vocabulary, which is important for communication, in its widest sense. Reading a text in its entirety builds confidence and consistent wide reading aids concentration for reading by expanding the learners' attention span. In addition skills learned through reading are transferred to other areas of language, such as writing, speaking and content areas. Extensive reading opens up a whole new world, enabling the reader to learn about other people, their cultures and outlooks as well as the reasons they behave in certain ways. This type of reading also sharpens judgment, as one's own outlook on life is broadened.

If, for no other reason, the ER programme should be encouraged and maintained because of its benefits for the language of the learner. The grounding of these benefits will spill over into other content areas and into writing, listening and speaking skills. However, the tragedy of nearly three quarters of schools in Kenya, especially those that are public is that: firstly, language lessons have been decreased at the national level from the original eight to six; secondly, teachers do not realize the arsenal that they have in an ER programme which they can exploit for the development of language of their students, and often do not strive to build ER programmes into their practice. Where teachers have any idea of the advantages of ER, it is not a priority of school administrations; thirdly, the government has no deliberate programmes that promote book publishing and distribution to supply schools with class readers, especially from (primary) - Standard five onwards.

So, what are some of the solutions?

- Have budgets that include class readers as part of government funding to schools.

- Have on-going teacher training especially in the languages of instruction, because these are the service languages for the education of learners. Everything else hangs on whether learners can understand what is before them- notes, questions, instructions.

- Increase language lessons - in secondary schools - for first and second forms so that one lesson can be designated an ER lesson and insist that each school does this.

- Insist that each registered school have libraries in their schools where learners can go and borrow books and read outside the designated textbooks and teachers' notes.

- Educate all teachers to realize the importance of effective language learning as a service to their subjects - geography, history, science, chemistry etc.

\section{Language Progress of Children and Children Leaving Primary School}

The observation of most children shows, on the one hand, that when they join primary schools they are able to:

» speak and understand mother tongue (i.e. the language of the home);

» adequately to express their needs;

» control the behavior of those around them;

» give and receive instructions, name objects around them, play using the language;

» utilize the language to form friendships; and

» express all sorts of emotions using the same.

\section{Alternative Ways of Building Class Libraries}

A visit to many schools showed that the only books and materials in what are called a library consist of old curriculum books that are no longer used. However, this does not have to be the case. Even where governments do not immediately allocate money for libraries, classes can begin mini-libraries where each pupil-buys a book from a list recommended by the language teacher which is then put into a pool. If there are 50 students, the learners in that class will have a choice of 50 readers to choose from throughout the year. This will form a wide basis for language learning and ER. Since each learner has contributed to the 
pool, rules will be generated to ensure that they take good care of the books. At the end of the year, each learner may still take back his/her book home, and the process can repeated when they get to the next class. Alternatively, these books can be used to build a school library that is vibrant and growing. The school can also have friends of the school donate books, journals and magazines, newspapers, and periodicals to be built into school libraries to which everyone has access. Friends of the school can also include publishing houses that will donate readers as part of their Corporate Social Responsibility (CSR).

\section{The Teacher}

The school, however, has many factors that affect what goes on there. The teacher is the center-piece of the school, even when they have the only textbook. The teacher's mastery of his/her subject, his/her ability to communicate the content to his/her learners in ways that they can understand, and to give pupils activities that are both meaningful and reinforcing of their need for actualization are key to effective learning. The factor that mediates both teaching and learning is language used to explain and understand the content taught in the various subjects. If content is not explained in language that is accessible to pupils, then they lose out. If questions are not phrased in language that pupils understand they may not express what they understand. On the other hand, if they understand questions, they may not have adequate facility in the language of learning to express what they know succinctly enough to score decent marks.

The process of teaching and learning is one that mediates many things such as perceptions of meaningfulness for learners in primary school, especially, to have a sense of discovery while in school and to enjoy what they are doing. They will not have this sense of enjoyment if the language is 'foreign', and they are struggling with both content and the former. The paper recommends the following:

\section{i) Pre-training Compensation}

Results have indicated that it is not only the learners that struggle with the language, but that teachers themselves also do struggle with the languages of instruction. Students enroll at the university with limited vocabulary, a great impediment to communication and academic success (Kembo, 1994). This will necessitate pre-service programmes in which the following gaps may be addressed:

- Extensive reading is made a compulsory part of the communication skills course. This would boost further and strengthen the language ability of those tasked with teaching and modeling the languages of instruction. In addition, there is need to have longer Communication Skills Programmes at college and university levels that are compensatory and aimed at significantly improving teacher trainees' language proficiency. The current token communication skills programmes are not addressing the ingrained language problems that learners bring with them from secondary school.

Is it possible to have language teachers trained for longer than other teachers? Or could language teachers, recognizing their role in learning, have higher qualifications for entering training as intending teachers? What are the knock-on effects of this?

\section{ii) After-training Improvement/Development Programmes}

When governments decide to develop comprehensive programmes for teacher development, one issue that may need careful consideration is the promotion of teachers and how this relates not only to years in service, but also to individual effort to access opportunities for self-improvement and professional growth. Teachers need to be encouraged every year to take some two week courses or more, of 'Teacher Development' Training. This will be in addition to their training, but can be on other teaching and learning or management related areas, or whatever is workable and necessary, in individual country circumstances. The Ministries of Education can work on these programmes in collaboration with colleges 
and university schools of education to give periodic trainings that are recognized both by the former and the teachers' employing bodies. This is one way of ensuring that teachers do not stagnate, but keep on developing in knowledge and skills.

Teacher promotions would, in addition to other requirements, be pegged on the number of courses that teachers have done or attended in any two or three years. A policy such as this would depend on ministries of education working in partnership with other bodies and institutions of learning to provide the trainings at subsidized costs to the teachers. Public private partnerships can also be encouraged as means of financing school and teacher improvements.

\section{Conclusion}

In conclusion, although it recognizes that there are other factors at play in children's education, this paper argues that the language factors play a major role and pervades all that learners attempt to do in school. The paper argues that school and teacher factors are important in language learning. Specifically:

- there should be policies that give every child a fighting chance in school, if we believe that school and development go together;

- the policies should be working and teachers trained adequately to carry them out by investing more on education systems that enhance human capital;

- avail resources that will enable learners to acquire the languages of instruction whether they are Foreign, or Second;

- the children can alternatively be taught in the first languages in which they are already proficient when they get to school and

- find creative ways of building and encouraging class libraries for extensive reading.

While the debate on which languages to teach our children in needs to go on, we must be cognizant that decisions must be made now and answers found that ensure children are not wasted in our school systems.

\section{References}

Amlaku, B. E. ( 2010). Language Policies and Role of English in Ethiopia. (A paper presented at the $23^{\text {rd }}$ Annual Conference of IATEFL BESIG) (19-21 Nov.2010). Beifeld, Germany.

Bangbose, A. (2005). Mother-tongue Education: Lessons from the Yoruba Experience. In Brock-Utne and R.F. Hopson (eds). Languages of Instruction for African Emancipation: Focus on Postcolonial Contexts and Considerations. Cape Town. CASAS.

Brock-Utne, B. (2007). The Continued Battle over Kiswahili as the Language of Instruction in Tanzania. In Brock-Utne and R.F. Hopson (eds). Languages of Instruction for African Emancipation: Focus on Postcolonial Contexts and Considerations. Cape Town. CASAS

Brock-Utne, B. (2007). Learning Through a Familiar Language versus Learning Through a Foreign Language -A look into Some Secondary School Classrooms in Tanzania. International Journal of Educational Development. 27.

Brock-Utne, B. and Koloti, M. S.(eds). Education for all-in Whose Language? Oslo: University of Oslo Press. 2007.

Chikalanga, I (1991). Inferencing in reading: A cross- cultural study. Unpublished Ph.D Thesis. University of Reading.

Edwards V. and Nwenmely, H.(1995). Language, Literacy, and World View. International Journal on Intercultural Relations, 19 ( 5).267-279.

Kembo, J. (1991). Methods of teaching literature. Nairobi: University of Nairobi Press.

Kembo, J. (1993). Reading: Encouraging and Maintaining Individual Extensive Reading. English 
Teaching Forum, April. 31, 2) 36-38.

Kembo, J. (1994). Inferencing in second language: How far is language proficiency a factor? (Unpublished PhD Thesis). University of Reading, UK.

Krashen, S. (2001). Free voluntary reading: Still a very good idea. Selected Papers from the Tenth International Symposium on English Teaching, 47-58. Taipei: Crane.

Krashen, S. (2002). Explorations in language acquisition and use: the Taipei lectures. Taipei: Crane Publishing Co., Ltd.

Kembo, J. (2013). Developing African Languages as Languages of Instruction and Education. (A paper presented to The Second Annual Transformation in Basic Education Summit, South Africa. July 15-17, 2013. Sun Hotel) Johannesburg, SA.

Kembo-Sure, E. (1995). Language attitudes and language proficinecy: A sociolinguistic study of English in Kenya. (Unpublished PhD Thesis) Moi University.

Kembo-Sure, E.and Ogechi, N. O. (2009). Linguisitic human rights and language policy in Kenya Educational System. Addis Ababa, OSSREA.

(2013). Literacy, Language, and Liberty: The Cultural Politics of English as Official Language in Africa. (In augural Lecture). Moi University Press. Kenya.

Kintsch, W. ( 1974). The Representation of Meaning in Memory. Hillsdale, NJ: Erlbaum.

Lunzer, E and Keith Gardner, (1979). From Learning to Read to Reading to Learn. In The effective use of reading. London: Spottis-Woode: Ballantyne.

Nutall, C. (1982). Teaching reading in Second Language. London: Heinemann.

Nzomo, J., Karuiki and Guantai, L.(2000). The quality of education: some policy suggestions based on a survey of schools. Paris: UNESCO.

Olshavsky, J. (1977). Reading as Problem Solving: An Investigation of Strategies. Reading Research Quarterly, 12, 654-674.

Tekeste, N. (2006). Education in Ethiopia: from crisis to the brink of collapse. Elanders Gotab AB: Stockholm.

Quorro, M. A. (2009). Parents' and Policy Makers' Insistence on Foreign Languages as Media of Education in Africa: Restricting access to quality education- for whose benefit? In Brock-Utne and I. Skattum (eds.). Languages and Education in Africa. Bristol: Symposium Books.

Uwezo (2011). Are our children Learning? Nairobi: Uwezo.

Uwezo (2012). Literacy and Numeracy Across East Africa. Nairobi: Uwezo.

Winne, P.H., Graham, L., and Prock L. (1993). A model of Poor Readers' Text-based Inferencing: Effects of Explanatory Feedback. Reading Research Quartely, 28 (1), 53-75.

Williams, E. (1994). First and Second language reading proficiency of Year 3, 4 and 6 Children in Malawi and Zambia. Reading in a Foreign Language, 10, (1), 915-930.

\section{About the Author}

Dr. Jane Kembo is faculty, Department of Curriculum Instruction and Media, Rongo University. 